\title{
Stage IIB Digestive System Neuroendocrine Tumor AJCC v7
}

National Cancer Institute

\section{Source}

National Cancer Institute. Stage IIB Digestive System Neuroendocrine Tumor A/CC v7. NCl Thesaurus. Code C88030.

Stage IIB includes: T3, NO, M0. T3: Stomach: tumor penetrates subserosa; jejunum/ileum: tumor invades through the muscularis propria into subserosal tissue without penetration of overlying serosa or invades into non-peritonealized tissues; ampulla/duodenum: tumor invades pancreas or retroperitoneum or into nonperitonealized tissues; colon or rectum: tumor invades through the muscularis propria into the subserosa, or into non-peritonealized pericolic or perirectal tissues. N0: No regional lymph node metastasis. M0: No distant metastasis. (AJCC 7th ed.) 